\title{
OBITUARIES
}

\section{ROBERT FLEMING HEIZER, 1915-1979}

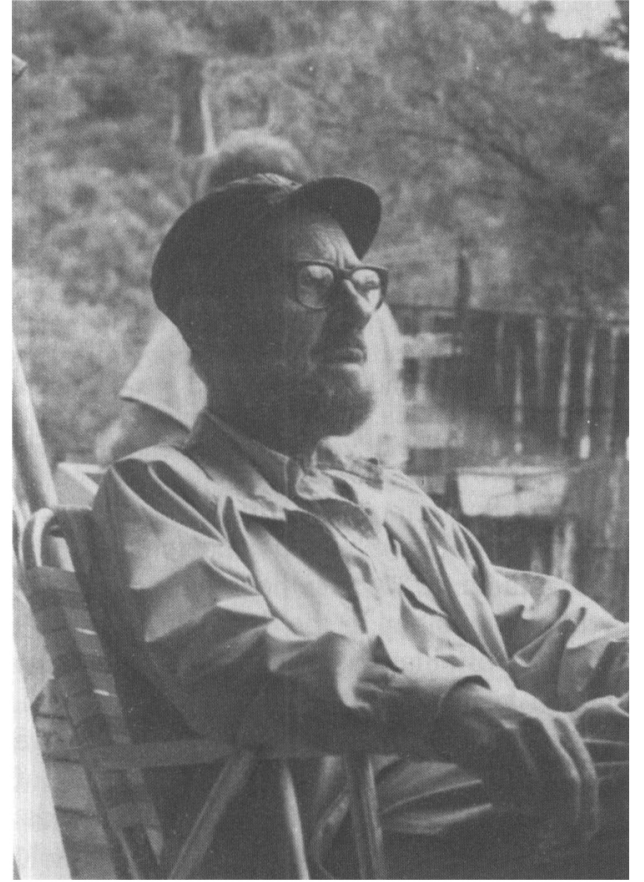

Robert Fleming Heizer was born on July 13, 1915, in Denver, Colorado, the son of Ott Fleming and Martha Madden Heizer. He married Nancy Elizabeth Jenkins in 1940 (they were divorced in 1975); they had two sons, Stephen and Michael, and a daughter, Sydney. Heizer died on July 18, 1979. He was initially hospitalized with cancer in June, 1978, although he had been in poor health for several months prior to that time. He waged a rugged battle against the disease, and despite its debilitating effects, continued research and teaching until a few days before his death.

Those are the basic statistics. What lies behind them is a brilliant anthropological career and a record of accomplishments that few can hope to attain. As I prepare this obituary, it has been two years since Bob Heizer's death. I thought that the passage of time would make this task easier, and I had hoped that a clearer view would emerge of his varied research and teaching activities. However, Heizer's activities were so broad and his influence so profound that it will be many years before we can best assess his impact on anthropology.

I knew Robert F. Heizer for 10 years, first as his graduate student (1969-1972) and then as a colleague, co-researcher, and close friend up to the time of his death. He had a complex personality; and this led to a number of stormy relationships with graduate students, not to mention some of his professional colleagues. While I am sure that many such encounters and feuds grew from a variety of causes, Heizer's primary explanations were that such persons were "not serious about archaeology" or that they did not "produce." Though we had an occasional disagreement, I suppose my singleminded, workaholic approach to archaeology was close enough to his so that a friendly bond was soon formed after I began my graduate studies at Berkeley.

Heizer's interests in the culture of the American Indian developed during his youth, much of it spent in Lovelock, Nevada. He was able to observe the surviving remnants of the Northern Paiute peoples and to collect artifacts from sites in the area. He did a lot of reading about Indians and archaeology. In one early incident his father contacted an acquaintance (perhaps a relative) who worked in Washington, D.C., and sought to secure copies of Smithsonian Institution publications for Bob. Shortly thereafter, a whole set of Bureau of American Ethnology Bulletins, Smithsonian Annual Reports, and related publications were dumped off, in crates, at the Lovelock train depot! Upon his graduation from Lovelock High School in 1932, Heizer knew that he wanted to go to Berkeley to study archaeology. However, the Lovelock school had an enrollment of only 70

Copyright (C) 1982 by the Society for American Archaeology 0002-7316/82/010099-09\$1.40/1 
students and several subjects required for admission to the university were not taught there. Heizer said (here and in some later passages I quote from unpublished reminiscences that he sent me in July 1973) that he "failed the College Entrance Examinations and was advised to go to a junior college" prior to entering what was then called the "State University."

He enrolled in Sacramento Junior College in September, 1932. He commented on an important event that occurred during registration:

along the line when someone noted that I wanted to be an archaeologist, I was pulled out of line and escorted to meet the president of the institution, Jeremiah Beverley Lillard-a sweet and dear person who had worked his way up through the city school system until he achieved the presidency of the junior college. From that time on, I became a special ward of his, and I can say that his interest was an important determinant in my life yet to come.

Through the common interest in archaeology that Heizer and Lillard shared, a great deal of fieldwork was done (and the basis laid for later investigations) in the Sacramento Valley and much of this was published (see Heizer [1974a]). Heizer provides these insights:

Lillard, untrained and uninformed, was at the same time extraordinarily perceptive and energetic, and he saw in some fashion which I could not, and can never divine, that one could recover the story of the Indian past by digging and studying the materials recovered. He was absolutely indefatigable, and on Saturdays we would go dig for Indian relics. . . . Always we dug where we hoped to find some poor old buried Indian whose grave would produce some interesting thing. . . . This was pothunting, pure and simple. But (this is not intended as an excuse), we were all interested in Indian culture, though not in the way contemporary archaeologists say they are.

After the experiences in Sacramento, Heizer went on to Berkeley, where he received an A.B. degree (with highest honors) at the University of California in 1936, and began his graduate studies in anthropology. There was little interest in local archaeology in the department at that time and therefore Heizer got a wide exposure to various subfields of anthropology from such teachers as Kroeber, Lowie, Gifford, and Olson. When it came time to write a dissertation, Kroeber did not want it done on an archaeological subject, and a study (only parts of which have been published) on aboriginal whaling in the Old and New Worlds resulted. Another key part of Heizer's training was his work in 1934 and 1935 with Aleš Hrdlička in the Aleutian Islands. Heizer liked to talk about those experiences with Hrdlička; more importantly, he saw through to publication, many years later, the findings of some of those investigations (Heizer 1956a, and several brief papers).

Heizer received his $\mathrm{Ph} . \mathrm{D}$. in 1941. His graduate school experience led to a long professional relationship with Kroeber for whom he had a tremendous respect, speaking of him fondly as "my teacher." Heizer and his family were living in Paris, where Bob was doing research at the Musée de l'Homme, at the time of Kroeber's death there in 1960.

Heizer's academic career began with a one-year appointment for 1940-1941 at the University of Oregon. During World War II, he worked for four years and four months as a marine pipefitter in the Richmond (California) shipyard. Following the war, he resumed teaching, this time as an instructor at the University of California at Los Angeles in 1945-1946. In addition to his full-time teaching (paid at the level of $\$ 1,800$ per year), he worked with sociologist Edwin Lemert at the Tank Site in Topanga Canyon (Heizer and Lemert 1947). His 30-year career in the department of anthropology at the University of California, Berkeley, began in 1946 with an appointment as Assistant Professor; in 1948 he was promoted to Associate Professor and in 1952 attained the rank of Professor. He worked closely with many students, both undergraduate and graduate. He particularly enjoyed working with a group of students that he had in the late 1940s and early 1950s (M. A. Baumhoff, J. A. Bennyhoff, A. B. Elsasser, Francis Riddell, and others); collaborative efforts among students and professor led to early versions of the field methods book as well as the popular volume, The Archaeologist at Work (Heizer 1959:xiii). Other student groups, beginning in the late 1960s and continuing through the 1970s, did extensive fieldwork in the Great Basin. In a posthumous volume now in press, Heizer writes that this was his happiest period as a teacher and 
researcher. A great deal of fieldwork and, of course, subsequent publication was done by students like C. William Clewlow, Jr., James F. O'Connell, Richard Ambro, Richard Cowan, Lewis K. Napton, Karen M. Nissen, James Bard, and Colin Busby. My own experiences as a student under him were particularly enlightening. I successfully resisted his efforts to steer me into the coprolite analysis program, and while I did my share of Great Basin research (most of the time being able to avoid strenuous fieldwork), we began to work more in the area of obsidian analysis, lithic use-wear and functional studies, typology, Egyptian quartzite research, and so on. I will always be grateful to him for paying so little attention to my earlier work in Texas and forcing me into other areas of inquiry!

Heizer often said that he did not regard himself as a good lecturer or, for that matter, as a particularly good teacher. I cannot personally evaluate the former in that I never had a lecture course from him. However, in seminars he seemed very effective in communicating with students. In terms of being a "good teacher," his strong suit was in working with students through research projects, by steering them into new methodological and theoretical approaches, putting them into contact with colleagues in other disciplines, and sharing with them his enormous knowledge of the archaeological literature. The hours spent by the student exploiting the vast resources of the various Berkeley libraries certainly paid off much more than any equivalent amount of time in the classroom. After his long and successful teaching career Heizer retired to emeritus status in January, 1976.

In addition to full-time teaching, and instructing field classes in the summers, Heizer also organized and directed the University of California Archaeological Survey from 1948 to 1960, when it was disbanded. The Survey was responsible for many major excavations and field studies in California, and Heizer personally saw to it that the results were promptly published in the 75 volumes of its Reports series. The style of the Reports was an inexpensive mimeographed one, as Heizer was more interested in rapid and wide dissemination of information than in a fancy format. The Survey was succeeded in 1960 by the Archaeological Research Facility, a research unit with broader goals. Heizer became coordinator of the Facility and served in this capacity until his retirement. A major publication series, the Contributions, was initiated and more than 35 volumes were published under his direct supervision. Several volumes dealt with Mesoamerican topics and resulted largely from the collaborative efforts of Heizer and John A. Graham. As with the Survey Reports, publication in the Contributions was quick; upon completion of a manuscript, Heizer saw that it went immediately into production. This often meant that he had to raise the money for printing, usually in a meeting over lunch with Dean Sanford Elberg.

During his career, Bob Heizer received numerous research grants. He took enormous pride in obtaining what he felt was just enough money to carry out a project; he then stretched every dollar for all it was worth in terms of fieldwork and publication. He often spoke with disdain of the size of many post-1970 funding requests (especially those for contract archaeology), and felt very strongly that they were exorbitant and a waste of taxpayers' dollars (cf. Heizer 1975:4-5). He received grants from the National Science Foundation, the National Geographic Society, the Wenner-Gren Foundation, the American Philosophical Society, and from a variety of private funding sources. I cannot find one of these which did not result in substantive archaeological rewards.

It is truly difficult to summarize Heizer's scholarly accomplishments. One can point to the nearly 500 publications and to the numerous honors that came to him as a result of his prodigious research efforts. These included an honorary Doctor of Science degree from the University of Nevada (1965), two Guggenheim Fellowships $(1963,1973)$, a year as a Fellow in the Center for Advanced Study in the Behavioral Sciences (1972-1973), an award for "Distinguished Scholarly Contributions" from the Southwestern Anthropological Association (1976), the Henry R. Wagner Medal of the California Historical Society (1977), and repeated listings in Who's Who in the World. However, he took greatest pride in his election to the National Academy of Sciences in 1973.

The roots of Heizer's devotion to scholarship must lie in his experiences in growing up in Nevada, perhaps aided by the crates of BAE Bulletins noted earlier. Certainly, the urge to do fieldwork, to study the materials, and to publish the findings was spurred by his association with 
Lillard at Sacramento Junior College. His proclivity for research must have been greatly enhanced by exposure to the library and museum collections at Berkeley while an undergraduate and graduate student, and through his mentor, Kroeber, and the other faculty members of that period. Heizer had an incredible grasp of the archaeological literature. He had a worldwide acquaintance with journals and other archaeological publications, a knowledge which he shared freely with his students.

Let us look at Heizer's record of publication. It is staggering both in terms of numbers, creativity, and anthropological diversity. An almost complete bibliography of Robert F. Heizer's works appears in the Journal of California and Great Basin Anthropology (Clark 1980), enhanced by a set of comments by Philip Wilke. My inventory of his publications is somewhat at variance with figures published earlier; this doubtless reflects the use of different publication lists and my inclusion of publications that appeared after his death. Heizer's scholarly output totals 494 items as of this writing (this number will go beyond 500 as there are several other papers still in preparation by several co-workers): (1) papers, reprinted papers, reports, prefaces: 410 ; (2) books (authored, co-authored, or edited): 29; (3) book reviews: 53 ; and (4) films: 2 .

It is impossible within the space limitations of this obituary to attempt any sort of detailed analysis of his publications. I will offer the following observations and refer the reader to evaluations by Clark (1980) and Baumhoff (1980). Heizer's publications are dominated by archaeology, principally on the prehistory of the Great Basin and California. Also figuring largely are works on Mesoamerican archaeology, especially on the Olmec, stimulated initially by his research with Philip Drucker at La Venta in 1955.

Interdisciplinary research (much of what would now be called archaeometry) is also very important in his publications. This is especially true of his collaboration with physiologist Sherburne F. Cook. Their innovative studies on the chemical analysis of human bone (Cook and Heizer 1950), midden constituent analysis (Cook and Heizer 1951), and on quantitative methods (Heizer and Cook 1960) are still important reference materials.

Among the other scientists with whom Heizer worked, and often published, were Howell Williams (geology; extensive studies of the stone sources for Olmec monuments; see Heizer and Williams [1965] ); Robert N. Jack (geochemistry; trace element research on Mesoamerican and Californian obsidians; see Jack and Heizer [1968] ]); Fred Stross [chemistry; see Heizer, Stross et al. [1973] regarding their collaborative work on the Colossi of Memnon quartzites); Frank Asaro, I. Perlman, and Harry Bowman, nuclear chemists at the Lawrence Berkeley Laboratory (Heizer, Stross et al. 1973; Bard et al. 1978); W. I. Follett (studies of fish remains); and Rainer Berger (radiocarbon analyses).

Heizer's publications also reflect a continuing interest in archaeological methods, and he was well known for his text on field methods first issued in 1949 (Heizer 1949a). His main approach to fieldwork, from my perspective and based on his own comments, was one of flexibility and adaptability: use what is best for the problem at hand and, above all, be observant and diligent in record-keeping. As he wrote in the Introduction to the 1975 edition of Field Methods in Archaeology (Hester et al. 1975): "There is nothing very exciting about techniques for recording data during an excavation-one simply has the obligation to record whatever information is there." He was, by his own account, an "old archaeologist," but one with a remarkable gift for careful field observations (rather than any rigorous adherence to long-range sampling goals); many solid site reports resulted from his field investigations.

A review of his publications reveals this sample of some of his other archaeological interests: the archaeology of hunters and gatherers, principally in California and the Great Basin (Heizer 1949b, 1956b, 1958, 1963a, 1978); early man in the western United States (Heizer 1952; Heizer and Brooks 1965; Heizer and Baumhoff 1965, 1970); historical archaeology (Heizer 1947a, 1950, 1974b; Heizer and Meighan 1952); rock art (Heizer and Baumhoff 1959, 1962; Heizer and Clewlow 1973); prehistoric technology and material culture studies (Heizer 1937, 1942, 1944, 1966b, 1968; Heizer and Johnson 1952; Heizer and Treganza 1944); archaeological bibliography (Heizer 1949c; Heizer and Elsasser 1970, 1977; Hester and Heizer 1973: Heizer, Hester, and Graves 1980); history of archaeology (Heizer 1962a, 1962b); dating techniques (Heizer 1953; Heizer and Ben- 
nyhoff 1958; Bard et al. 1978); cultural ecology and related topics, especially coprolite analysis (Heizer 1956c, 1963b, 1967, 1970a, 1970b, 1978; Heizer and Napton 1969); general archaeological issues and theoretical concerns (Heizer 1960, 1962c, 1963c, 1966a, 1974c, 1975), and experiments in archaeology (Graham et al. 1972; Heizer and Graham 1971; Hester and Heizer 1973).

Heizer, working with Frank Hole, co-authored one of the most widely used introductory texts in archaeology; it has gone through three editions (Hole and Heizer 1965, 1969, 1973), and a restructured, briefer version was published in 1977 (Hole and Heizer 1977).

An interest in the transport of ancient heavy monuments was kindled in Heizer through his work with Olmec colossal sculpture. He began a research program that was worldwide in scope (Heizer 1966b) and which later led to a project in Egypt in 1971 and 1972, funded by the National Geographic Society. On the west bank of Thebes at Luxor, Heizer and his team studied the New Kingdom statues known as the Colossi of Memnon. Trace element analysis, using the techniques of nuclear chemistry, was employed to determine the quarry origins; then, the aim was to study the attendant problems of transport and placement of these 720-ton monoliths. Through the efforts of Stross, Perlman, Asaro, and Bowman, this project was successfully completed (Heizer, Stross et al. 1973) and remains, as far as I know, the only research of its sort yet carried out with Egyptian monuments. The methodology developed through the work of the project still has tremendous potential. As was typical of most Heizer projects, the Colossi investigations had spinoffs, particularly an ethnoarchaeological study of contemporary Egyptian stone-vase manufacture, carried out by Heizer, John Graham, and the writer (Hester and Heizer 1981a, 1981b).

Thorough reports on a number of major sites are found among Heizer's publications. These include Humboldt Cave (Heizer and Krieger 1956), Lovelock Cave (Heizer and Napton 1970), the Eastgate shelters (Heizer and Baumhoff 1961), La Venta, Tabasco (Drucker et al. 1959), Uyak, Alaska (Heizer 1956a), and Hum-67, California (Heizer and Elsasser 1964). In addition to the areas represented by these sites, Heizer also did fieldwork in Peru, Egypt, Guatemala, and Texas. In the year prior to his death, he worked with his friend, Giancarlo Ligabue and the Centro Studi e Ricerche Ligabue (he was a member of the Centro's Scientific Committee) on the planning of fieldwork slated for the Maya site of Colha, Belize. His deteriorating health kept him from going into the field during the first season at the site in spring, 1979.

Throughout his career, Heizer published extensively on the ethnology and ethnohistory of the Indians of California and Nevada. Baumhoff (1980) has dealt with this research facet in some detail in his Arnerican Anthropologist obituary of Heizer (see, as examples, Heizer 1947b, 1966c, 1976; Heizer and Almquist 1971; Heizer and Elsasser 1980; Kroeber et al. 1977; Heizer and Kroeber 1979; Kroeber and Heizer 1968; Heizer and Whipple 1951, 1971). His interest in California Indians went beyond the scholarly level. This included his work with Kroeber on the Indian claims cases in 1954-1955 and his personal involvement as a consultant to the Legal Assistance Program for California Indians. He wrote eloquently, and often bitterly, about the treatment of the native peoples of California (Heizer 1974d). He has been honored, since his death, by a symposium held in October 1980 by the American Society for Ethnohistory. This organization has also established an annual Robert F. Heizer Memorial Prize for the best annual article using an ethnohistorical approach.

Aside from writing, which he loved and which he seemingly did almost continuously, Bob Heizer greatly enjoyed the chores of editing. This was expressed in several books, the Archaeological Survey Reports, most of the Archaeological Research Facility Contributions up to 1976, and as one of several editors for the University of California Publications in American Archaeology and Ethnology (as well as in the Anthropological Records also published by that university). He was also on the editorial board of a number of journals. With the help of Gerald O'Neal he started the Ballena Press Publications on Archaeology, Ethnology and History 14 volumes had been published at the time of his death). He assembled and closely edited the California volume of the Handbook of North American Indians (Volume 8). Typically, the job was efficiently seen through to completion, and it was the first volume to be issued (1978) in this major publication. Heizer had long maintained that there was a need for a statewide anthropological journal for California and he was 
thus one of a group of people who helped start the Journal of California Anthropology (and its successor, the Journal of California and Great Basin Anthropology). Through his direct interest, funding for the support of the Journal was secured from several private donors.

Finally, in regard to Heizer's extensive publications, it should be noted that much of his work was collaborative in nature. He took much pleasure from such research and the exchange of ideas that it engendered. Most such collaboration was with students and colleagues; for example, there were 5 to 10 (or more) papers and books each with M. A. Baumhoff, C. William Clewlow, Philip Drucker, Albert Elsasser, Franklin Fenenga, John A. Graham, and Lewis K. Napton. I worked with him on more than 20 papers and books. An equal amount of collaborative research was done with colleagues from other scientific disciplines, all of whom I have mentioned earlier; at least 16 papers resulted from his joint research with S. F. Cook.

Heizer as a person was most typified by his incredible energy. He was competitive, aggressive, and did not shrink from controversy. He tremendously enjoyed fieldwork and the challenges and prospects of discovery that it presented. If conditions deteriorated he responded to the challenge and worked harder, as I well remember in two quite different environs: recording Nevada rock art in a snow flurry and documenting the Colossi of Memnon in $122^{\circ}$ heat! His energy extended, as we have already seen, to publication, for in his view, fieldwork, a laboratory project, or any type of archaeological endeavor was worth nothing unless it was published.

To say he was energetic about archaeology is indeed an understatement. He was obsessed with archaeology. Lunches on Telegraph Avenue, airplane journeys, sitting in a bar in the Winter Palace Hotel at Luxor-all were locales for Heizer to take pen in hand, get out one of his ubiquitous yellow note pads, and proceed to outline a paper, develop some ideas for a future project, or jot down another reference to be squirreled away until the next revision of one of his many books.

I found him to be a very generous person, particularly with his time, his knowledge, and his experience. He had a keen wit and an engaging, albeit sardonic, sense of humor. I more than once expected that we would be tossed out of a restaurant or bumped off an airplane as Bob mumbled out incisive commentary on an inept waiter or offered his pointed appraisal of some fellow traveler. And many situations called forth a joke or anecdote derived from his fondness for the writings of Mark Twain.

Robert F. Heizer leaves a considerable legacy to archaeology, in terms of fundamental and often far-reaching research and more than three decades of teaching and lecturing. He made a number of gifts of books and special literature collections to several institutions: collections on rock art went to UCLA and to The University of Texas at San Antonio. At the latter, there is also a special collection of publications on Olmec archaeology and an archive of obsidian studies. His personal notes and records on La Venta and on other facets of his research went to the Smithsonian Institution. Heizer's personal and professional letters, as well as assorted research notes, are now in the archives of the Bancroft Library at the University of California, Berkeley. His extensive library on the building, engineering, and transport of ancient stone monuments is currently being used to complete a book that he had underway at the time of his death. Bob Heizer also leaves many students, colleagues, and friends who admired him immensely and who will greatly miss him.

THOMAS R. HESTER

\section{REFERENCES CITED}

Bard, J. C., F. Asaro, and R. F. Heizer

1978 Perspectives on the dating of prehistoric Great Basin petroglyphs by neutron activation analysis. Archaeometry 20:85-88.

Baumhoff, M. A.

1980 Robert Fleming Heizer, 1915-1979. American Anthropologist 82:843-847. 
Clark, J. D.

1980 Memorial to Robert Fleming Heizer (1915-1979). Journal of California and Great Basin Anthropology 1:241-245. [Includes almost complete bibliography.]

Cook, S. F., and R. F. Heizer

1950 On the methods of chemical analysis of bone as an aid to prehistoric culture chronology. University of California Archaeological Survey Report 7:10-14.

1951 The physical analysis of nine Indian mounds of the lower Sacramento Valley. University of California Publications in American Archaeology and Ethnology 40:281-312.

Drucker, P., R. F. Heizer, and R. Squier

1959 Excavations at La Venta, Tabasco, 1955. Bureau of American Ethnology, Bulletin 1970.

Graham, J. A., R. F. Heizer, and T. R. Hester

1972 A bibliography of replicative experiments in archaeology. Archaeological Research Facility, Berkeley.

Heizer, R. F.

1937 Baked clay objects of the lower Sacramento Valley, California. American Antiquity 3:34-50.

1942 Ancient grooved clubs and modern rabbit-sticks. American Antiquity 8:41-56.

1944 Artifact transport by migratory animals and other means. American Antiquity 9:395-400.

1947a Archaeological investigation of Sutter Sawmill site in 1947. California Historical Society Quarterly 26:134-159.

1947b Francis Drake and the California Indians, 1579. University of California Press, Berkeley.

1949a A manual of archaeological field methods. The National Press, Milbrae, California (first rev. ed., 1950; second rev. ed., 1953; third rev. ed., 1958; with new title, A Guide to Archaeological Field Methods.]

$1949 \mathrm{~b}$ The archaeology of Central California. I: the early horizon. University of California Anthropological Records 12:1-84.

1949c A bibliography of the archaeology of California. University of California Archaeological Survey Report 4:1-27.

1950 Observations on historic sites and archaeology in California. University of California Archaeological Survey Report 9:1-5.

1952 A review of problems in the antiquity of man in California. University of California Archaeological Survey Report 16:3-17.

1953 Long range dating in archaeology. In Anthropology today, edited by A. L. Kroeber, pp. 3-42. University of Chicago Press, Chicago.

1956a Archaeology of the Uyak site, Kodiak Island, Alaska. University of California Anthropological Records 17:1-200.

1956b Recent cave explorations in the lower Humboldt Valley, Nevada. University of California Archaeological Survey Report 33:50-57.

1956c Primitive man as an ecologic factor. Kroeber Anthropological Society, Papers 13:1-31.

1958 Prehistoric central California: a problem in historical-developmental classification. University of California Archaeological Survey Report 41:19-26.

1959 The archoeologist at work. Harper \& Row, New York (reprinted 1967, 1975).

1960 Agriculture and the theocratic state in lowland southeastern Mexico. American Antiquity 26:215222.

1962a The background of Thomsen's three-age system. Technology and Culture 3:259-266.

1962b Man's discovery of his past. Spectrum Books No. S-46. Prentice-Hall, Englewood Cliffs, N.J.

1962C Inferences on the nature of Olmec society based upon data from the La Venta Site. In A. L. Kroeber Memorial Volume, pp. 43-57. Kroeber Anthropological Society, Berkeley.

1963a The western coast of North America. In Prehistoric man in the New World, edited by J. Jennings and E. Norbeck, pp. 117-148. University of Chicago Press, Chicago.

1963b Domestic fuel in primitive society. Journal of the Royal Anthropological Institute 93:186-194.

1963c The possible sociopolitical structure of the La Venta Olmecs. Proceedings of the XXXIV International Congress of Americanists, Vienna, 1960:310-317.

1966a Salvage and other archaeology. The Masterkey 40:54-60.

1966b Ancient heavy transport: methods and achievements. Science 153:821-830.

1966c Languages, territories and names of California Indian tribes. University of California Press, Berkeley.

1967 Analysis of human coprolites from a dry Nevada cave. University of California Archaeological Survey Report 70:1-20.

1968 Migratory animals as dispersal agents of cultural materials. Science 161:914-915.

1970a The anthropology of prehistoric Great Basin coprolites. In Science in archaeology, edited by D.

Brothwell and E. Higgs, pp. 244-250. Thames and Hudson, London.

$1970 \mathrm{~b}$ Environment and culture: the Lake Mohave case. The Masterkey 44:68-76.

1974a Studying the Windmiller culture. In Archaeological researches in retrospect, edited by G. R.

Willey, pp. 179-206. Winthrop Publishers, Cambridge, Mass.

1974b Elizabethan California. Ballena Press, Ramona, Calif. 
1974C A question of ethics in archaeology-one archaeologist's view. Journal of California Anthropology 1:145-151.

$1974 \mathrm{~d}$ The destruction of California Indians. Peregrine-Smith, Salt Lake City.

1975 Some thoughts on California archaeology at the moment. Journal of New World Archoeology 1:1-13.

1976 The Indians of California: a critical bibliography. Newberry Library Center for the History of the American Indian, Bibliographical Series. Chicago.

1978 Man the hunter-gatherer: food availability versus biological factors. In Progress in human nutrition (Vol. 2), edited by S. Margen and R. Ogar, pp. 10-23. Avi Publishing, Westport, Connecticut.

Heizer, R. F., and A. J. Almquist

1971 The other Californians: prejudice and discrimination under Spain, Mexico and the United States to 1920. University of California Press, Berkeley.

Heizer, R. F、, and M. A. Baumhoff

1959 Great Basin petroglyphs and prehistoric game trails. Science 129:904-905.

1961 The archaeology of two sites at Eastgate. Churchill County. Nevada: Part I. Wagon Jack Shelter. University of California Anthropological Records 20:119-138.

1962 Prehistoric rock art of Nevada and Eastern California. University of California Press, Berkeley.

1965 Postglacial climate and archaeology in the Desert West. In The Quaternary of the United States, edited by H. E. Wright and D. G. Frey, pp. 697-707. Princeton University Press, Princeton.

1970 Big game hunters in the Great Basin. a critical review of the evidence. University of California Archaeological Research Facility Contribution 7:1-12.

Heizer, R. F., and J. A. Bennyhoff

1958 Cross-dating Great Basin sites by Californian shell beads. University of California Archaeological Survey Report 42:60-92.

Heizer, R. F., and R. A. Brooks

1965 Lewisville-ancient campsite or wood rat houses? Southwestern Journal of Anthropology 21:155-165.

Heizer, R. F,, and C. W. Clewlow

1973 Prehistoric rock art of California. 2 vols. Ballena Press, Ramona, California.

Heizer, R. F., and S. F. Cook (editors)

1960 The application of quantitative methods in archaeology. Viking Fund Publications in Anthropology 28.

Heizer, R. F., and A. B. Elsasser

1964 Archaeology of Hum-67, the Gunther Island site in Humboldt Bay. California. University of California Archaeological Survey Report 62:5-122.

1970 A bibliography of California archaeology. University of California Archaeological Research Facility Contribution 6:1-78.

1977 A bibliography of California Indians: archaeology, ethnography, Indian history. Garland Publishing. New York.

1980 The natural world of the California Indians. University of California Press, Berkeley.

Heizer, R. F., and J. A. Graham

1971 Replicative experiments in archaeology. Studia Ethnographica et Folkloristica in Honorem Bela Gunda, pp. 175-181. Debrecen, Hungary.

Heizer, R. F., T. R. Hester, and C. Graves

1980 Archaeology, a bibliographical guide to the basic literature. Garland Publishing, New York.

Heizer, R. F., and I. W. Johnson

1952 A prehistoric sling from Lovelock Cave. Nevada. American Antiquity 18:139-147.

Heizer, R. F., and A. D. Krieger

1956 The archaeology of Humboldt Cave, Churchill County, Nevada. University of California Publications in American Archaeology and Ethnology 47:1-190.

Heizer, R. F, and T. Kroeber (editors)

1979 Ishi, the last Yahi: a documentary history. University of California Press, Berkeley.

Heizer, R. F., and E. Lemert

1947 Observations on archaeological sites in Topanga Canyon, California. University of California Publications in American Archaeology and Ethnology 44:237-258.

Heizer, R. F., and C. W. Meighan

1952 Archaeological exploration of sixteenth century Indian mounds at Drake's Bay. California Historical Quarterly 31:98-108.

Heizer, R. F., and L. K. Napton

1969 Biological and cultural evidence from prehistoric coprolites. Science 165:563-568.

1970 Archaeological investigations in Lovelock Cave, Nevada. University of California Archaeological Research Facility Contribution 10:1-86.

Heizer, R. F., F. Stross, T. R. Hester, A. Albee, I. Perlman, F. Asaro, and H. Bowman 1973 The Colossi of Memnon revisited. Science 182:1219-1225.

Heizer, R. F., and A. E. Treganza

1944 Mines and quarries of the Indians of California. California Journal of Mines and Geology 40:291-359. (Reprinted in 1972 by Ballena Press, Ramona, California.) 
Heizer, R. F., and M. A. Whipple (editors)

1951 The California Indians. University of California Press, Berkeley.

1971 The California Indians: a sourcebook (second ed.). University of California Press, Berkeley.

Heizer, R. F., and H. Williams

1965 Sources of rocks used in Olmec sculpture. University of California Archaeological Research Facility Contribution 1:1-40.

Hester, T. R., and R. F. Heizer

1973 Bibliography of archaeology: I: experiments, lithic technology, and petrography. Addison-Wesley Module in Anthropology 29.

1981a Making stone vases: contemporary manufacture of material culture items in Upper Egypt. In Modern material culture, edited by R. Gould and M. Schiffer, pp. 283-302. Academic Press, New York.

1981b Making stone vases: ethnoarchaeological studies at an alabaster workshop in Upper Egypt. Undena Publications, Malibu, Calif.

Hester, T. R., R. F. Heizer, and J. A. Graham

1975 Field methods in archaeology (sixth ed.). Mayfield Publishing, Palo Alto, Calif.

Hole, F., and R. F. Heizer

1973 An introduction to prehistoric archaeology. Holt. Rinehart \& Winston, New York. (Also 1965, 1969.)

1977 Prehistoric archaeology: a brief introduction. Holt, Rinehart \& Winston, New York.

Jack, R. N., and R. F. Heizer

1968 "Finger-printing" of some Mesoamerican obsidians. University of California Archaeological Research Facility, Contributions 5:81-100.

Kroeber, T., A. B. Elsasser, and R. F. Heizer

1977 Drawn from life: California Indians in pen and brush. Ballena Press, Socorro, New Mexico.

Kroeber, T., and R. F. Heizer

1968 Almost ancestors: the first Californians. Sierra Club, San Francisco. 